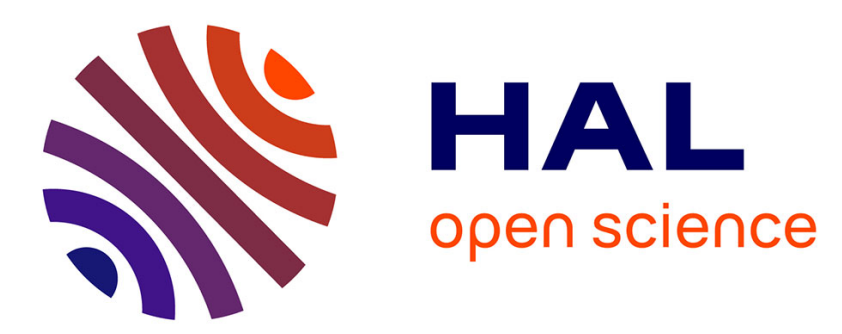

\title{
Seasonal variability of denitrification efficiency in northern salt marshes: An example from the St. Lawrence Estuary
}

Patrick Poulin, Emilien Pelletier, Richard Saint-Louis

\section{- To cite this version:}

Patrick Poulin, Emilien Pelletier, Richard Saint-Louis. Seasonal variability of denitrification efficiency in northern salt marshes: An example from the St. Lawrence Estuary. Marine Environmental Research, 2007, 63 (5), pp.490. 10.1016/j.marenvres.2006.12.003 . hal-00562966

\section{HAL Id: hal-00562966 https://hal.science/hal-00562966}

Submitted on 4 Feb 2011

HAL is a multi-disciplinary open access archive for the deposit and dissemination of scientific research documents, whether they are published or not. The documents may come from teaching and research institutions in France or abroad, or from public or private research centers.
L'archive ouverte pluridisciplinaire HAL, est destinée au dépôt et à la diffusion de documents scientifiques de niveau recherche, publiés ou non, émanant des établissements d'enseignement et de recherche français ou étrangers, des laboratoires publics ou privés. 


\section{Accepted Manuscript}

Seasonal variability of denitrification efficiency in northern salt marshes: An example from the St. Lawrence Estuary

Patrick Poulin, Emilien Pelletier, Richard Saint-Louis

PII:

S0141-1136(06)00222-4

DOI:

10.1016/j.marenvres.2006.12.003

Reference:

MERE 3085

To appear in:

Marine Environmental Research

Received Date: $\quad 2$ June 2006

Revised Date: $\quad 11$ December 2006

Accepted Date: $\quad 12$ December 2006

Please cite this article as: Poulin, P., Pelletier, E., Saint-Louis, R., Seasonal variability of denitrification efficiency in northern salt marshes: An example from the St. Lawrence Estuary, Marine Environmental Research (2006), doi: 10.1016/j.marenvres.2006.12.003

This is a PDF file of an unedited manuscript that has been accepted for publication. As a service to our customers we are providing this early version of the manuscript. The manuscript will undergo copyediting, typesetting, and review of the resulting proof before it is published in its final form. Please note that during the production process errors may be discovered which could affect the content, and all legal disclaimers that apply to the journal pertain. 


\section{Seasonal variability of denitrification efficiency in northern salt marshes: An example from the St. Lawrence Estuary}

Patrick Poulin, Emilien Pelletier and Richard Saint-Louis

Institut des Sciences de la Mer de Rimouski (ISMER),

Université du Québec à Rimouski,

310 allée des Ursulines, Rimouski (Québec), Canada, G5L 3A1

*Corresponding author

e-mail : Emilien_Pelletier@uqar.qc.ca

Tel : (418) 723-1986 ext 1764

FAX : (418) 724-1842

Manuscript review no. 5650

Last revision: December $4^{\text {th }}, 2006$ 


\section{$\underline{\text { Abstract }}$}

In coastal ecosystems, denitrification is a key process in removing excess dissolved nitrogen oxides and participating in the control of eutrophication process. Little is known about the role of salt marshes on nitrogen budgets in cold weather coastal areas. Although coastal salt marshes are important sites for organic matter degradation and nutrient regeneration, bacterial-mediated nitrogen cycling processes, such as denitrification, remain unknown in northern and sub-arctic regions, especially under winter conditions. Using labelled nitrogen $\left({ }^{15} \mathrm{~N}\right)$, denitrification rates were measured in an eastern Canadian salt marsh in August, October and December 2005. Freshly sampled undisturbed sediment cores were incubated over $8 \mathrm{~h}$ and maintained at their sampling temperatures to evaluate the influence of low temperatures on the denitrification rate. From 2 to $12{ }^{\circ} \mathrm{C}$, average denitrification rate and dissolved oxygen consumption increased form 9.6 to $25.5 \mu \mathrm{mol} \mathrm{N}_{2} \mathrm{~m}^{-2} \mathrm{~h}^{-1}$ and from 1.3 to $1.8 \mathrm{mmol} \mathrm{O}_{2} \mathrm{~m}^{-2} \mathrm{~h}^{-1}$, respectively, with no statistical dependence of temperature $(\mathrm{p}>0.05)$. Nitrification has been identified as the major nitrate source for denitrification, supplying more than $80 \%$ of the nitrate demand. Because no more than $31 \%$ of the nitrate removed by sediment is estimated to be denitrified, the presence of a major nitrate sink in sediment is suspected. Among possible nitrate consumption mechanisms, dissimilatory reduction of nitrate to ammonium (DNRA), metal and organic matter oxidation processes are discussed. Providing the first measurements of denitrification rate in a St. Lawrence Estuary salt marsh, this study evidences the necessity of preserving and restoring marshes. They constitute an efficient geochemical filter against an excess of nitrate dispersion to coastal waters even under cold northern conditions. 


\section{ACCEPTED MANUSCRIPT}

Keywords: Biogeochemical cycle, Denitrification, Ice, Nutrients, Salt marshes,

Sediments, Stable isotopes. 


\section{$\underline{\text { Introduction }}$}

Denitrification is the dissimilatory reduction of nitrogen oxides $\left(\mathrm{NO}_{2}{ }^{-} ; \mathrm{NO}_{3}{ }^{-}\right)$to gaseous nitrogen $\left(\mathrm{N}_{2}\right)$. A large group of anaerobic bacteria of the genus Pseudomonas, synthesizing different types of reductases, can use reduced nitrogen oxides as electron acceptors in the absence of oxygen (Knowles, 1981). Denitrification is recognised as the key process to maintain nitrogen limitation in coastal waters (Howarth, 1988). It removes excess dissolved inorganic nitrogen loads (Seitzinger,1988), decreasing the amount of fixed nitrogen available to the primary producers (Nixon, 1981). As a consequence, denitrification is important in controlling the eutrophication level in coastal environments (eg. Nowicki et al., 1997) that are increasingly affected by anthropogenic nutrient inputs (Cloern, 2001). The exposure of terrestrial organic matter and nutrient inputs to estuaries (Gearing and Pocklington, 1990) leads to high primary productivity and high organic matter deposition, and therefore results in high bacterial mineralization, which causes a depletion of oxygen supplies in the sedimentary compartment (Duarte, 1995).

Formed in the upper littoral zone of mid and high latitudes, coastal salt marshes are known as a major feature of macrotidal estuaries (Jickells and Rae, 1997). Affected strongly by tidal flooding and by riverine runoff, marsh areas act as an important bioprocessor of nitrogen species (Aziz and Nedwell, 1986) which play many critical ecological and economic roles (Boorman, 1990). Although the nitrogen cycle in NorthWest Atlantic Coast and Western Europe temperate salt marshes (Kaplan et al., 1979; Aziz and Nedwell, 1986; Koch et al., 1992; Thompson, 1995; Eriksson et al., 2003) has been studied extensively, our understanding of the dynamic of sub-arctic marsh environments is still incomplete, specially during winter time when sea ice covers littoral 
areas. There is still lack of knowledge about biogeochemical processes in these icy environments, especially the nitrogen cycle and the rate of microbial-mediated nitrogen transformations such as denitrification. As the first step toward predicting decennial behaviour of cold coastal ecosystems under the actual scenario of global coastal eutrophication (Cloern, 2001; Jickells, 2005), it is essential to determine rates and pathways by which fixed nitrogen is metabolised by bacteria.

The main objective of this study is to evaluate seasonal denitrification rates in a northern salt marsh subject to frozen conditions for four months of year. Using labelled nitrate $\left({ }^{15} \mathrm{NO}_{3}{ }^{-}\right)$(Nielsen, 1992), denitrification rates were measured in Pointe-au-Père salt marsh sediment (St. Lawrence Estuary, Québec, Canada) in August, October and December 2005; with weather conditions corresponding to summer, fall and winter, respectively. Freshly sampled intact cores were incubated under in situ temperatures to evaluate the influence of temperature on $\mathrm{N}_{2}$, dissolved inorganic nitrogen (DIN) and $\mathrm{O}_{2}$ fluxes resulting from denitrification and mineralization processes. During the late experiment in December, sediment cores were collected under a thin ice cover to quantify denitrification rates under the coldest conditions occurring in this coastal region. The quantitative significance of denitrification as well as relative contribution of biochemical processes, such as organic matter mineralization to the cold salt marsh nitrogen cycle, has been discussed. These are the first direct measurements of the denitrification rates in a St. Lawrence Estuary salt marsh and provide the first estimates of the relative importance of denitrification as a nitrate removal process in northern estuaries. 


\section{Materials and methods}

\section{Studied site}

The Pointe-au-Père salt marsh $\left(48^{\circ} 30^{\prime} 30^{\prime \prime} \mathrm{N}, 68^{\circ} 28^{\prime} 30^{\prime \prime} \mathrm{W}\right)$ is located on the south shore of the St. Lawrence Estuary in the city of Rimouski (Québec, Canada) (Fig. 1). This marsh has been part of the Pointe-au-Père National Wildlife Area protected by Canadian Wildlife Service (Environment Canada) since September 2002. Confined in an elongated basin parallel to the main Estuary axis and sheltered from wave action by a longitudinal Palaeozoic structure, this 22.6 ha marsh is dominated by areas with homogenous emergent macrophyte (Spartina alterniflora) communities surrounded by vegetation-free network creeks. Due to its low slope, the floodwater complexly spreads over marsh area during semi-diurnal cyclic tidal excursion; tidal water enters by a large inlet at the western border, progresses laterally and smoothly over mud flats, as energy of the incoming tide is dissipated by friction on the inner bay. Located in a partly urbanised watershed, this marsh receives nitrogenous inputs in micro-molar concentrations from both agricultural and urban runoff (Av $\left.\pm \mathrm{SD} ; 7.29 \pm 16.43 \mathrm{~kg}^{\mathrm{DIN} \mathrm{d}} \mathrm{d}^{-1}\right)$. This freshwater runoff enters the salt marsh by two main drainage channels along the south-east border $\left(0.28 \pm 0.59 \mathrm{~m}^{3} \mathrm{~s}^{-1}\right)$. In addition, the St. Lawrence coastal zone is subject to important seasonal variations, which affects water temperature and salinity in response to heat flux and freshwater discharge. One of the main features of Saint-Lawrence cold salt marshes is the formation of sea ice that begins in early December and persists until April. This ice cover plays an important role in littoral ecosystems. Although sea ice erodes tidal flats, it 
protects the intertidal zone from wave action and generates singular sedimentary structures (Dionne, 1998; Drapeau, 1992; Serodes and Dubé, 1983).

\section{Sampling procedure}

For each experiment (carried out in August, October and December 2005), 18 sediment cores (5 to $10 \mathrm{~cm}$ long x $9.8 \mathrm{~cm}$ i.d.) were collected at low tide in the same 10 $\mathrm{m}^{2}$ area showing homogenous and specific surface characteristics (Fig. 1) using a tubular aluminium corer $(100 \mathrm{~cm}$ long x $9.8 \mathrm{~cm}$ i.d.). To minimize perturbation of superficial sediment, the corer was slowly pushed into the sediment and the core was recovered using a small shovel. Each sediment core was delicately truncated at $3 \mathrm{~cm}$ below the sediment surface, to obtain a $3-\mathrm{cm}$ long x $9.8 \mathrm{~cm}$ i.d. core, and was carefully transferred to a Plexiglas tube $(14.5 \mathrm{~cm}$ long x $9.8 \mathrm{~cm}$ i.d.) later used as incubation chambers. Tubes with cores were transported to the laboratory within 30 minutes to minimize alteration of natural biogeochemical equilibria, and wraped in aluminium foil to avoid photochemical reactions. In addition, $50 \mathrm{~L}$ of surface sea water was collected from the Pointe-au-Père biological station pier (Fig. 1) and stored in an acid pre-cleaned polypropylene bottle to perform incubation; whose salinity, dissolved oxygen and nitrate level is $25 \pm 2,10 \pm 2$ $\mathrm{mg}^{-1}$ and $1.8 \mu \mathrm{M}$ (August) 14.7 $\mu \mathrm{M}$ (December), respectively.

\section{Laboratory incubations}

In the laboratory, tubes were placed in a temperature controlled room set at the temperature measured in sediment cores at the sampling site (i.e. 12,6 , and $2{ }^{\circ} \mathrm{C}$ for August, October and December, respectively). The tubes were labelled from 1 to 18 and 
sealed at the bottom with rubber stoppers. Tubes 1 to 8 were used for denitrification measurements, tubes 9 to 12 were used for nitrate $\left(\mathrm{NO}_{3}{ }^{-}\right)$and ammonium $\left(\mathrm{NH}_{4}{ }^{+}\right)$flux measurements whereas tubes 13 to 16 were used for dissolved oxygen $\left(\mathrm{O}_{2}\right)$ flux measurements. These 16 caped tubes (named incubation chambers) were incubated in the dark, using a large temperature-controlled water bath equipped with a stirring system (shaking table type), set at the temperature corresponding to the sampling season. The incubation period was fixed at $8 \mathrm{~h}$ to avoid expected development of hypoxic conditions $\left(\left[\mathrm{O}_{2}\right]<2 \mathrm{mg} \mathrm{l}^{-1}\right)$ in the overlying water layer, since preliminary data obtained over the last three years showed that Pointe-au-Père salt marsh water column is year around well oxygenated. The remaining two sediment cores, kept in tubes 17 to 18 , were freeze-dried and homogenised for determination of sediment characteristics, including carbon and nitrogen element, particle size, trace metal and total hydrolysable amino acid (THAA).

\section{Denitrification activity}

For the denitrification rate determination, seawater $(500 \mathrm{ml})$ enriched with 35 to $45 \mu \mathrm{M} \mathrm{K}^{15} \mathrm{NO}_{3}$ (98 atom $\%{ }^{15} \mathrm{NO}_{3}$, Aldrich) was transferred in tubes 1 to 8 , giving a water layer of about $7 \mathrm{~cm}$ height and an air head-space of $\sim 2 \mathrm{~cm}(281 \mathrm{ml})$. The concentration of $\mathrm{NO}_{3}{ }^{-}$in typically impacted salt marsh water was $\sim 20 \mu \mathrm{M}$. Tubes were capped with rubber stoppers equipped with gas-tight sampling ports and stirred for 10 min using a stirring table set at $~ 60$ RPM to ensure homogenization of spiked nitrate. Then, a 5-ml water sample was sampled and replaced by ambient air (using 5-ml gastight syringe) to measure the initial concentration of $\mathrm{NO}_{3}{ }^{-}$and therefore the initial concentration of ${ }^{15} \mathrm{NO}_{3}{ }^{-}$was calculated. Tube air head-space was sampled (using a $10 \mu \mathrm{l}$ 
gas-tight syringe) to measure the initial $\mathrm{N}_{2}$ isotopic composition. After an 8-h incubation period, sediment cores were manually shaken for $2 \mathrm{~min}$ in order to equilibrate pore water gases with the overlying water. Air head-space of each chamber was sampled once again to measure final $\mathrm{N}_{2}$ isotopic composition. Before each sampling, the gas-tight syringe and the GC-IRMS injection port were flushed with helium. After collection, air samples were immediately introduced in the GC gas port for isotopic composition determination to avoid a gas storage step and contamination risks.

\section{Nitrogen species and dissolved oxygen fluxes}

The procedure described previously was applied to the 8 remaining incubation tubes, but labelled $\mathrm{K}^{15} \mathrm{NO}_{3}$ was replaced by unlabelled $\mathrm{KNO}_{3}$. These chambers were incubated without gas head-space and were sampled hourly during the 8-h incubation, using 5 and $25 \mathrm{ml}$ gas-tight syringes. For $\mathrm{NO}_{3}{ }^{-}$flux measurements, water samples $(5 \mathrm{ml})$ were taken from tubes 9 to 12 , transferred into 5 -ml cryovials and stored at $-80{ }^{\circ} \mathrm{C}$ for further analysis. The same procedure was applied to measure $\mathrm{NH}_{4}{ }^{+}$fluxes except that water samples were analysed immediately after sampling. The remaining four chambers (13 to 16) were used for $\mathrm{O}_{2}$ flux measurements as $25-\mathrm{ml}$ water samples were transferred in volumetric glass bottles and analysed without delay. To avoid depressurisation in chambers, sampled water was replaced by an identical volume of ambient air.

Using denitrification rate measurement via direct determination of air head-space $\mathrm{N}_{2}$ isotopic enrichment from immerged sediments (Nielsen, 1992) can avoid some of the problems associated with indirect approaches (e.g. Sorensen, 1978). However, despite their advantages, the labelled $\mathrm{N}_{2}$ flux technique suffers of some artefacts mainly caused 
by the non-equilibrium conditions imposed by closed chambers (Hamersley and Howes, 2005), particularly for $\mathrm{O}_{2}$. Since sediment cores were incubated without considering diurnal tidal inundation and dewatering cycle, photosynthetic $\mathrm{O}_{2}$ production as well as atmospheric advection, sedimentary $\mathrm{O}_{2}$ supply was blocked. This artefact could alter chamber chemical conditions (affecting the redox structure of sediment core and the equilibrium between dissolved ionic compounds in the pore water and onto sedimentary particles), and affect the balance between aerobic and anaerobic heterotrophy as well as the overall measured nitrification-denitrification rates (Risgaard-Petersen, 2003). By opting for an experimental design including short incubation period, relatively large gas headspace and water thicknesses, we minimised measurement errors and artefacts linked to closed incubation chambers.

\section{Analyses}

Isotopic composition of air head-space $\mathrm{N}_{2}\left({ }^{14} \mathrm{~N}^{14} \mathrm{~N},{ }^{14} \mathrm{~N}^{15} \mathrm{~N}\right.$ and $\left.{ }^{15} \mathrm{~N}^{15} \mathrm{~N}\right)$ was determined using a gas chromatograph/combustion/isotope ratio mass spectrometer system (GC/C/IRMS Delta XP Plus ${ }^{\circledR}$, Thermo Finnigan equipped with a Conflo III interface). Gas samples $(10 \mu \mathrm{l})$ were injected manually in the GC inlet and nitrogen species were separated isothermally at $125^{\circ} \mathrm{C}$ by gas chromatography using a DB5 $30 \mathrm{~m}$ capillary column ( $0.25 \mathrm{~mm}$ i.d.) with helium as the vector gas and were combusted in an oxidation and reduction furnace at 850 and $650{ }^{\circ} \mathrm{C}$ respectively. The gas samples were then passed through a cryogenic trap (liquid nitrogen) to remove water vapour and condensable gases followed by the alternative introduction of pure $\mathrm{N}_{2}$ reference gas and $\mathrm{N}_{2}$ samples into the mass spectrometer for ${ }^{14} \mathrm{~N}^{14} \mathrm{~N},{ }^{14} \mathrm{~N}^{15} \mathrm{~N}$ and ${ }^{15} \mathrm{~N}^{15} \mathrm{~N}$ peaks area 
determination. The retention time for $\mathrm{N}_{2}$ was $150 \mathrm{sec}$ and mass peaks were integrated over $120 \mathrm{sec}$.

Dissolved $\mathrm{O}_{2}$ was measured using the standard Winkler titration method (Strickland and Parson, 1968), $\mathrm{NO}_{3}{ }^{-}$dosages were made by classical colorimetric technique (Strickland and Parson, 1968) using an automated analytic Bran+Luebbe AA3 ${ }^{\circledR}$ platform whereas $\mathrm{NH}_{4}{ }^{+}$concentrations were determined using a micro-plate base fluorometric technique (Poulin and Pelletier, 2006). Sediment core elementary analyses for carbon and nitrogen $\left(\mathrm{C}_{\text {org }} / \mathrm{N}_{\text {tot }}\right)$ were performed with a ECS 4010 Costech $^{\circledR}$ instrument equipped with a zero blank auto sampler, using certified sediment sample $(n=10)$ NIST$1941 b$ as a reference, whereas granulometric analyses were done with Coulter ${ }^{\circledR}$ counter model LS13320C. Trace metals (Mn and Fe) were measured in $0.5 \mathrm{~g}$ dry sediment samples according to Anschutz et al.(2000). Extraction was carried with $35 \mathrm{ml}$ of $1 \mathrm{~N}$ $\mathrm{HCl}$ for $6 \mathrm{~h}$. The solutions were centrifuged, superrnatant was diluted in $1 \% \mathrm{HCl}$ and analysed in normal mode with an inductively coupled plasma mass spectrometer (ICPMS Agilent $\left.{ }^{\circledR} 7500 \mathrm{c}\right)$ equipped with a micro-nebulizer. Metals were quantified with an external linear calibration curve established from standard solutions (Multielements standards solution IV, Fluka Chemie, Sigma-Aldrich). Total hydrolysable amino acids (THAA) were measured in $0.5 \mathrm{~g}$ freeze-dried, homogenised sediment samples. After hydrolysis with $10 \mathrm{ml}$ of $6 \mathrm{~N} \mathrm{HCl}$ at $100{ }^{\circ} \mathrm{C}$ for $24 \mathrm{~h}$, the supernatant acid solution was centrifuged, diluted and neutralized with $2 \mathrm{~N} \mathrm{NaOH}$. The solutions were analysed on a Shimadzu ${ }^{\circledR}$ LC 10AD VP HPLC system using a Agilent ${ }^{\circledR}$ C-18 column $(4.6$ X 250 mm, 5 $\mu \mathrm{m})$ and a Water $^{\circledR} 470$ fluorescence detector $\left(\lambda_{\mathrm{ex}}=230 \mathrm{~nm}, \lambda_{\mathrm{em}}=445 \mathrm{~nm}\right)$ after derivatisation with o-phthaldialdehyde and 2-mercaptoethanol (Lindroth and Mopper, 
1979) using phosphate buffer and methanol gradient. Individual amino acids were identified and quantified using amino acid standard solution (Sigma ${ }^{\circledR}$ ) which contained 21 amino acids and ammonium chloride.

\section{$\underline{\text { Calculations }}$}

Total denitrification rates (Dt) were calculated from chamber air-space ${ }^{15} \mathrm{~N}$ enrichment according to Nielsen (1992). The labelled ${ }^{15} \mathrm{~N}$ concentration was estimated by multiplying its isotopic ratios $\left({ }^{14} \mathrm{~N}^{15} \mathrm{~N} /\right.$ total $\mathrm{N}_{2}$ and ${ }^{15} \mathrm{~N}^{15} \mathrm{~N} /$ total $\left.\mathrm{N}_{2}\right)$ by the calculated $\mathrm{N}_{2}$ concentration in the air trapped in the head-space and in water layer knowing the distribution coefficient of $\mathrm{N}_{2}$ in sea water as a function of temperature (Weiss, 1970). $\mathrm{NO}_{3}{ }^{-}$denitrification rates coming from overlying water (Dw) and denitrification rates of $\mathrm{NO}_{3}{ }^{-}$produced within the sediment by nitrification (Dn) were calculated using equations below. These equations require three main assumptions: 1) the total amount of ${ }^{14} \mathrm{~N}^{14} \mathrm{~N}$ inside the incubation chamber does not change during the sample collection period, 2) the

${ }^{15} \mathrm{~N}$ labelling of the $\mathrm{NO}_{3}^{-}$in the sediment is uniform, 3) ${ }^{14} \mathrm{~N}^{15} \mathrm{~N}$ and ${ }^{15} \mathrm{~N}^{15} \mathrm{~N}$ constitute $0.7299 \%$ and $0.001 \%$ of total $\mathrm{N}_{2}$ in the air (Nielsen, 1992).

$\mathrm{D} 15=\left({ }^{14} \mathrm{~N}^{15} \mathrm{~N}\right)+2\left({ }^{15} \mathrm{~N}^{15} \mathrm{~N}\right)$

$\mathrm{D} 14=\mathrm{D} 15 \times\left({ }^{14} \mathrm{~N}^{15} \mathrm{~N}\right) / 2\left({ }^{15} \mathrm{~N}^{15} \mathrm{~N}\right)$

$\mathrm{Dw}=\mathrm{D} 15 \times\left[{ }^{14} \mathrm{NO}_{3}{ }^{-}\right] /\left[{ }^{15} \mathrm{NO}_{3}{ }^{-}\right]$ 
$\mathrm{Dt}=\mathrm{D} 15+\mathrm{D} 14$

$\mathrm{Dn}=\mathrm{Dt}-\mathrm{Dw}$

The ${ }^{14} \mathrm{NO}_{3}{ }^{-}$concentrations were determined in overlying water in incubation chambers before ${ }^{15} \mathrm{NO}_{3}{ }^{-}$addition whereas ${ }^{15} \mathrm{NO}_{3}{ }^{-}$concentrations were measured as a concentration increase in water after the addition.

Diagenetic alteration of sedimentary amino acids was assessed using the Degradation Index (DI) developed by Dauwe and Middelburg (1998) and Dauwe et al. (1999). This index is based on the first axis of a Principal Component Analysis (PCA) of the amino acid composition and summarizes, in one variable, the relative cumulative variation of 14 amino acids (aspartic acid, glutamic acid, serine, histidine, thréonine, arginine, glycine, tyrosine, alanine, méthionine, valine, phenylalanine, isoleucine and leucine). DI values were calculated from amino acids average molar concentration, standard deviation and predetermined coefficient factors (i.e. first axis of the Principal Component Analysis from the comprehensive data set of Dauwe et al., 1999). The DI sign indicates a depletion (-) or an enrichment (+) of labile organic nitrogen protein in sediment.

Pearson correlations were performed in first instance to assess the relationship between pairs of variables considering correlation significance at $\mathrm{p}<0.05$ level. Thereafter a One-Way Analysis of Variance (ANOVA) was performed to test the significant effect of a fixed factor (temperature) on dependant variables (denitrification, oxygen and nitrate consumptions and ammonification). To isolate groups that differed 
from the others, a Tukey post-hoc test was performed. When ANOVA assumptions were not respected, a Kruskal-Wallis One-Way Analysis of Variance on Ranks was performed followed by a Dunn's post-hoc test. Differences between groups were considered significant at the $\mathrm{p}<0.05$ level. Comparisons of means were performed with Sigma Stat ${ }^{\circledR}$ version 3.11 from SyStat Software Inc.

\section{$\underline{\text { Results }}$}

Sediment analysis revealed that all cores exhibited quite uniform characteristics with organic carbon abundance ranging from 6.5 to $9.0 \%, \mathrm{C} / \mathrm{N}$ values ranging from 13.2 to 19.4 , average particle size ranging from 109 to198 $\mu \mathrm{m}$, manganese and iron concentrations ranging from 0.04 to $0.08 \mu \mathrm{mol} \mathrm{g}^{-1}$ (d.w.) and from 4.17 to $4.84 \mu \mathrm{mol} \mathrm{g}^{-1}$ (d.w.), respectively (Table 1).

Total denitrification rates $(\mathrm{Dt}=\mathrm{Dw}+\mathrm{Dn})$ measured in Pointe-au-Père salt marsh sediment varied from 5.73 to $15.01 \mu \mathrm{mol} \mathrm{N} \mathrm{m}^{-2} \mathrm{~h}^{-1}$ at $2{ }^{\circ} \mathrm{C}$, from 11.18 to $24.62 \mu \mathrm{mol} \mathrm{N} 2$ $\mathrm{m}^{-2} \mathrm{~h}^{-1}$ at $6{ }^{\circ} \mathrm{C}$, and from 18.36 to $42.24 \mu \mathrm{mol} \mathrm{N}_{2} \mathrm{~m}^{-2} \mathrm{~h}^{-1}$ at $12{ }^{\circ} \mathrm{C}$. Measured Dt rates increased with temperature but this trend is not statistically significant ( $\mathrm{p}>0.05)$ (Fig. 2) due to a large range of values observed for each series of measurements. For the same initial nitrate addition, Dt rates remained important even under the lowest temperature since the average rate at $2{ }^{\circ} \mathrm{C}$ was only 2.6 fold lower than the one determined at $12{ }^{\circ} \mathrm{C}$. Denitrification coming from overlying water (Dw) averaged 15, 6 and $2 \%$ of Dt rates at 2, 6 and $12{ }^{\circ} \mathrm{C}$, respectively. Although representing a minor contribution to Dt rates, Dw values were statistically correlated to temperature $(\mathrm{p}=0.001)$. Denitrification produced within the sediment by nitrification (Dn) represented the main contribution to Dt rates. 
Statistically correlated to temperature $(\mathrm{p}=0.038)$, Dn contributed for 85,94 and $98 \%$ of Dt rates at 2,6 and $12{ }^{\circ} \mathrm{C}$, respectively.

Dissolved oxygen sediment consumption rates also showed an increasing trend with temperature, which ranged from 1.25 to $1.43 \mathrm{mmol} \mathrm{O}_{2} \mathrm{~m}^{-2} \mathrm{~h}^{-1}$ at $2^{\circ} \mathrm{C}$, from 1.59 to $1.70 \mathrm{mmol} \mathrm{O}_{2} \mathrm{~m}^{-2} \mathrm{~h}^{-1}$ at $6{ }^{\circ} \mathrm{C}$, and from 1.63 to $1.94 \mathrm{mmol} \mathrm{O}_{2} \mathrm{~m}^{-2} \mathrm{~h}^{-1}$ at $12{ }^{\circ} \mathrm{C}$; but this was not statistically significant $(\mathrm{p}>0.05)$ (Fig. 3). However, sediment nitrate consumption and ammonium generation rates were both statistically correlated to temperature $\left(\mathrm{p}=0.001\right.$ and 0.04 , respectively). Between 2 and $6{ }^{\circ} \mathrm{C}$, nitrate and ammonium fluxes remained statistically identical (ranging from 59.25 to $139.41 \mu \mathrm{mol}$ $\mathrm{NO}_{3}{ }^{-} \mathrm{m}^{-2} \mathrm{~h}^{-1}$ and 2.61 to $69.70 \mu \mathrm{mol} \mathrm{NH}{ }^{+} \mathrm{m}^{-2} \mathrm{~h}^{-1}$ ) whereas they significantly increased at $12{ }^{\circ} \mathrm{C}$ (215.52 to $296.79 \mu \mathrm{mol} \mathrm{NO}{ }_{3}^{-} \mathrm{m}^{-2} \mathrm{~h}^{-1}$ and 205.56 to $248.62 \mu \mathrm{mol} \mathrm{NH}{ }^{+} \mathrm{m}^{-2} \mathrm{~h}^{-1}$ ) (Fig. 4). This observation is expected to be closely linked to the increase of microbial activity with the temperature (Sundback et al., 2000). In addition, a significant linear correlation was observed between nitrate consumption and ammonium generation rates ( $\mathrm{r}$ $=0.90)$, which indicated a possible mechanistic relationship between these two processes in salt marsh sediment.

A typical HPLC profile of total hydrolysable amino acids (THAA) is given in figure 5 showing the dominance of aspartic and glutamic acids, serine, threonine and alanine in salt marsh sediment. THAA concentrations measured in triplicate on one core sampled during summer time (early in August 2005), reached 55.71 $\pm 5.61 \mu \mathrm{mol} \mathrm{g}^{-1}(\mathrm{n}=$ 3). The average DI value calculated for Pointe-au-Père salt marsh sediment $(-0.67 \pm 0.02$; $n=3$ ) was below the range of values usually obtained for coastal sediments (from -0.35 
to 1.01) as reported by Dauwe et al., (1999) indicating that organic matter in sediment was in an advanced state of decomposition (Table 1).

\section{$\underline{\text { Discussion }}$}

A large body of information is available on factors influencing denitrification in coastal marine environments (see review by Herbert, 1999). The three main factors influencing benthic denitrification are temperature, supplies of $\mathrm{NO}_{3}{ }^{-}$and availability of organic carbon (Smith et al., 1985; Yoon and Benner, 1992; Tuominen et al., 1998). Despite these factors, denitrification rates values measured in our cold salt marsh sediments are comparable with those obtained by other workers along the North-West Atlantic Coast and in Western Europe temperate salt marshes (e.g. Great Sippewissett Marsh (New England, USA) 0-357 $\mu \mathrm{mol} \mathrm{N} \mathrm{m}^{-2} \mathrm{~h}^{-1}$, Kaplan et al., 1979; Colne Point Marsh (England) 2.6-6.4 $\mu \mathrm{mol} \mathrm{N}_{2} \mathrm{~m}^{-2} \mathrm{~h}^{-1}$, Aziz and Nedwell, 1986; Torridge Marsh (England) 2.51-59.0 $\mu \mathrm{mol} \mathrm{N}_{2} \mathrm{~m}^{-2} \mathrm{~h}^{-1}$, Koch et al., 1992; New Port Marsh (North Carolina, USA) 0-14.6 $\mu \mathrm{mol} \mathrm{N} \mathrm{m}^{-2} \mathrm{~h}^{-1}$, Thompson., 1995; Lagoon of Venise (Italia) 0$160 \mu \mathrm{mol} \mathrm{N} \mathrm{N}^{-2} \mathrm{~h}^{-1}$, Eriksson et al., 2003). Although a part of the variation in published denitrification rates could be related to differences in experimental designs, values reported here indicate that the denitrifying process is efficient in cold salt marsh sediments, even under winter conditions. Due to the lack of a significant relationship between mean Dt rate and temperature of incubation, the direct effect of temperature was difficult to assess when dissolved oxygen and nutrient concentration variations in the overlying water were taken into account. Temperature effects were weak since mean Dt rate at $2{ }^{\circ} \mathrm{C}$ was only 2.6 fold lower than during incubation at $12{ }^{\circ} \mathrm{C}$ (Fig. 2). Although the 
high variability of measured denitrification rates needs to be considered to explain the lack of significant relationship between mean Dt rates and temperature, the incidence of coupled bacterial processes and favourable chemical conditions such as high $\mathrm{NO}_{3}{ }^{-}$ availability should be considered. In addition, this result could indicate the combined contribution of a cold-adapted microbial population, which dominated winter time moderate denitrification activity, with a higher temperature optimum population being active during summer (Blackburn and Sorensen, 1988). However, no information is available on bacterial population succession in the study area.

Denitrification is recognised to be limited by $\mathrm{NO}_{3}^{-}$supplies and hence by nitrification in coastal sediments (Jenkins and Kemp, 1984). In our study, nitrification is the main source of $\mathrm{NO}_{3}{ }^{-}$for denitrification, with an average Dn rate contribution reaching $98 \%$ of Dt rate at $12{ }^{\circ} \mathrm{C}$. Since Dn was statistically correlated to temperature, this result suggests that the coupling between nitrification and denitrification is thermo-dependant and consequently could be more important under summer than winter conditions in a cold salt marsh environment. The relative contribution of Dw to Dt could therefore explain the observed seasonal trend of denitrification rates. Dw rates, expected to increase with the in situ $\mathrm{NO}_{3}{ }^{-}$concentration, was negatively related to temperature $(\mathrm{p}=0.001)$. Because in situ $\mathrm{NO}_{3}{ }^{-}$concentration was higher in December $(14.7 \mu \mathrm{M})$ than in August $(1.8 \mu \mathrm{M})$ in the St. Lawrence Estuary surface water, due to the incidence of sea ice on primary producers (data not shown), Dw contribution to Dt tends to mask seasonal denitrification variation (since the same ${ }^{15} \mathrm{NO}_{3}^{-}$amendment was used for each experiment). These results indicate a control of $\mathrm{Dw}$ by $\mathrm{NO}_{3}{ }^{-}$concentrations and suggest that $\mathrm{NO}_{3}{ }^{-}$could play a substantial role in Dt limitation in cold salt marsh environment. 
Aerobic respiration is related to temperature in coastal sediment (Thamdrup et al., 1998; Silverberg et al., 2000). However, no statistical relationship can be demonstrated (p > 0.05) between oxygen consumption rates and temperature in our study (Fig. 3). We hypothesize that aerobic microbial mineralization processes, predominantly responsible for oxygen consumption, are affected mainly by the quality and quantity of sedimentary organic matter and much less by temperature. Even if elementary analysis revealed no significant trend in organic carbon content with seasons (Table 1), more organic matter is available in salt marsh sediment during fall than at the end of summer (Valiela et al., 1976). Since available organic matter may increase during autumn period when dead vegetation is added to marsh, it could have increased the overall sediment oxygen consumption during incubation carried in October as well as in December. Thus, carbon availability is low in summer but potential oxygen consumption rates are high because of warmer temperatures, while in fall/winter, carbon availability is high but potential rates are limited by colder temperatures. Alternatively, a greater proportion of carbon degradation could take place during the warmer months via alternative oxidation pathways such as sulphate, iron or manganese reduction.

Average $\mathrm{NO}_{3}{ }^{-}$consumption (molecular ratio) represented 46, 42 and $86 \%$ of $\mathrm{O}_{2}$ respiration rates at 2,6 and $12{ }^{\circ} \mathrm{C}$, respectively, showing that $\mathrm{NO}_{3}{ }^{-}$plays a determining role as a terminal electron acceptor for organic matter mineralization. On the other hand, we estimated that no more than $31 \%$ of $\mathrm{NO}_{3}{ }^{-}$removed by salt marsh sediment at $6^{\circ} \mathrm{C}$ was subsequently denitrified (based upon the highest $\mathrm{Dt} / \mathrm{NO}_{3}{ }^{-}$consumption ratio). Because nitrate consumption largely exceeded denitrification, alternative $\mathrm{NO}_{3}{ }^{-}$reduction pathways in sediment are suspected. Dissimilatory $\mathrm{NO}_{3}{ }^{-}$reduction to $\mathrm{NH}_{4}{ }^{+}$(DNRA) by 
heterotrophic bacteria has been reported as very important $\mathrm{NO}_{3}{ }^{-}$reduction pathway in shallow coastal environments (An and Gardner, 2002). On a molar ratio basis, $\mathrm{NH}_{4}{ }^{+}$ average flux reached $89 \%$ at $12{ }^{\circ} \mathrm{C}$ and $29 \%$ at 6 and $2{ }^{\circ} \mathrm{C}$ of the average $\mathrm{NO}_{3}{ }^{-}$ consumption (Fig. 4). This result and the observed significant positive correlation between nitrate consumption and ammonium generation rates $(\mathrm{r}=0.90)$ could indicate that a coupling exists between these two processes in cold salt marsh sediment. However, before considering this coupling, we need to evaluate the relative contribution of both ammonification processes $\left(\mathrm{NH}_{4}{ }^{+}\right.$bacterial production from organic matter and DNRA processes) on $\mathrm{NH}_{4}{ }^{+}$generation rates. Although we did not measure ${ }^{15} \mathrm{NH}_{4}{ }^{+}$enrichment from ${ }^{15} \mathrm{NO}_{3}{ }^{-}$amendment in this study (to determine DNRA rates), the calculated DI (0.67) from THAA measurement as well as the $\mathrm{C} / \mathrm{N}$ ratio (13.2-19.4) of organic matter suggest that marsh sediment possessed only a small amount of labile organic material readily available for biologic mineralization (Table 1).

Mainly related to bacterial, phytoplanktonic and zooplanktonic cell plasma material (Dauwe and Middelburg, 1998), aspartic acid, glutamic acid, serine, threonine and alanine stand for this labile organic matter pool (Fig. 5). Although amino acids from proteins are the major organic nitrogen source to microbial ammonification (Pantoja and Lee, 2003), the quantitative mineralization of THAA present in marsh sediment $(55.71 \pm$ $\left.5.61 \mu \mathrm{mol} \mathrm{g}{ }^{-1}\right)$ can not be used to explain the observed $\mathrm{NH}_{4}{ }^{+}$flux $(228.51 \pm 21.67 \mu \mathrm{M}$ $\mathrm{NH}_{4}{ }^{+} \mathrm{m}^{2} \mathrm{~h}^{-1}$ ). Thus, we suggest DNRA constitute a significant nitrogen recycling process in this sedimentary environment. This assumption is supported by a study carried by King and Nedwell (1985) which shows that $\mathrm{NO}_{3}{ }^{-}$concentration contributed to determine either how much $\mathrm{NO}_{3}{ }^{-}$is lost to $\mathrm{N}_{2}$ or preserved as $\mathrm{NH}_{4}{ }^{+}$in anaerobic salt marsh sediment. 
These authors demonstrated that a low $\mathrm{NO}_{3}{ }^{-}$concentration $\left(\left[\mathrm{NO}_{3}{ }^{-}\right]<236 \mu \mathrm{M}\right)$ can enhance DNRA whereas a high $\mathrm{NO}_{3}{ }^{-}$concentration promoted denitrification. In addition, Joye and Hollibaugh, (1995) showed that sulphur compounds can inhibit denitrification and enhance DNRA. Since only a low ${ }^{15} \mathrm{NO}_{3}{ }^{-}$concentration was used in this study (corresponding to natural level) and particularly because the presence of sulphur compounds was suspected in our salt marsh samples (presence of hydrogen sulphide odour during sampling) DNRA should be investigated in cold salt marsh sediment as a key $\mathrm{NO}_{3}{ }^{-}$removal process.

Another $\mathrm{NO}_{3}{ }^{-}$sedimentary sink that can be invoked in this study is the $\mathrm{NO}_{3}{ }^{-}$ reduction by $\mathrm{Mn}^{2+}$. In anoxic sediment, dissolved oxidants present in pore water are recognised to be actively used by heterotrophic bacteria as terminal electron acceptor for OM oxidation, leading to the reduction of oxidized metals. Partially reduced metal, such as $\mathrm{Mn}^{2+}$, can be re-oxidised to $\mathrm{MnO}_{2}$ by $\mathrm{NO}_{3}{ }^{-}$in the absence of oxygen (Luther et al., 1997). Although this abiotic process could contribute to nitrogen cycling, reduced Mn likely played a marginal contribution in measured $\mathrm{NO}_{3}^{-}$flux considering low $\mathrm{Mn}^{2+}$ concentration $\left(0.04-0.08 \mu \mathrm{mol} \mathrm{g}{ }^{-1}\right)$ measured in salt marsh sediment (Table 1) compared to St. Lawrence Estuary surface sediment (13.4- $92.8 \mu \mathrm{mol} \mathrm{g}^{-1}$; Anschutz et al., 2000).

Results based on field and laboratory studies (Simek and Cooper, 2002) determinede that denitrification processes measured in cold salt marshes would not be a significant source of $\mathrm{N}_{2} \mathrm{O}$. These authors showed that denitrification end products were mostly determined by sediment $\mathrm{pH}$ with low $\mathrm{N}_{2} \mathrm{O} / \mathrm{N}_{2}$ production ratios in more neutral sediment. Because $\mathrm{pH}$ of flooding estuarine water in the Pointe-au-Père marsh varied from 6.5 to 8.5 (data not shown), denitrification should mostly produce $\mathrm{N}_{2}$. Although 
both environments might be different, dinitrogen was the exclusive product of denitrification in the Tagus Estuary salt marsh sediment (Cartaxana and Lloyd, 1999). High organic content and low oxygen concentration were assumed to increase the demand for electron acceptors in salt marsh sediment, preventing $\mathrm{N}_{2} \mathrm{O}$ emission by denitrification. In addition, a recent study on a coastal embayment located in Eastern Canada reported very low $\mathrm{N}_{2} \mathrm{O}$ production from denitrification ranging from undetectable to 40 pmol N $\mathrm{O} \mathrm{l}^{-1} \mathrm{~d}^{-1}$ (Punshon and Moore, 2004).

The relatively high microbial organic matter degradation propensity observed in salt marsh surface sediment (Table 1) coupled with high nitrate uptake capacity measured in this study argue for a significant role of salt marsh in estuarine annual $\mathrm{N}$ and $\mathrm{C}$ budget. The reduced vascular plant canopy and coarse salt marsh sediment favour the development of benthic microbial communities involved in $\mathrm{N}$ and $\mathrm{C}$ biochemical cycles (Aspen et al., 2004). Nevertheless, since St. Lawrence Estuary marshes are affected strongly by erosion (Dionne, 1986), these areas actually might appear insignificant in regard to estuarine bottom sediment surface $\left(\sim 3000 \mathrm{~km}^{2}\right)$. While they represented only 90 $\mathrm{km}^{2}$ in 1986 (Dionne, 1986), these marsh areas are becoming more vulnerable to increased erosive forces (Morisette, 2006). Thus, it is clear that marsh areas need restoration effort to recover a significant contribution to the whole St. Lawrence estuarine system because these ecosystems possess a strong nutrient regeneration potential. Concerning the nitrogen cycle, measured sedimentary denitrification and $\mathrm{NO}_{3}{ }^{-}$ consumption rates on this study were, in average, $\sim 6$ times higher than rates measured in deep sediments of the St. Lawrence marine system (1.8-3.3 $\mu$ mol $\mathrm{N}_{2} \mathrm{~m}^{-2} \mathrm{~h}^{-1}$; and 13.9$25.5 \mu \mathrm{mol} \mathrm{NO}_{3}{ }^{-} \mathrm{m}^{-2} \mathrm{~h}^{-1}$; Wang et al., 2003). In addition, assuming that $2.4 \mathrm{~mol}$ of $\mathrm{N}_{2}$ are 
produced through the mineralization of $6 \mathrm{~g}$ of elemental carbon (Gottschalk, 1979), we can estimate the denitrification contribution to the carbon salt marsh cycle at $<64 \mu \mathrm{g} \mathrm{C}$ $\mathrm{m}^{-2} \mathrm{~h}^{-1}$ (using average summer time denitrification rate value). This carbon mineralization rate resulting from denitrification is 16 times higher than the one defined for the Laurentian Through by Wang et al. (2003) evaluated at $4.125 \mu \mathrm{g} \mathrm{C} \mathrm{m}{ }^{-2} \mathrm{~h}^{-1}$ (based on a denitrification rate of $3.3 \mu \mathrm{mol} \mathrm{N} \mathrm{m}^{-2} \mathrm{~h}^{-1}$ ).

Because this study focused only on one specific site, we cannot extrapolate our results to the whole St-Lawrence Estuary intertidal system. On the other hand, these results combined with those of Wang et al., (2003) support the idea that cold salt marsh environments appear to be an efficient year-round sinks for nitrate, which could contribute to the whole St. Lawrence estuarine denitrification capacity if actions are taken to increase substantially their surface. This study shows that denitrification accounts for a variable fraction of $\mathrm{NO}_{3}{ }^{-}$reducing processes and alternative pathways, such as DNRA, appear important in salt marsh sediment, especially during summer. Further investigations should be undertaken to explain the relative contribution of these two processes as well as seasonal changes in $\mathrm{NO}_{3}{ }^{-}$reducing bacterial population in this area. Considering that coastal wetlands are being lost worldwide (Boorman, 1999), our results highlight the importance of preserving and restoring northern salt marsh areas, as they are part of an efficient geochemical filter against nitrate dispersion to coastal waters. 


\section{$\underline{\text { Acknowledgement }}$}

Authors acknowledge G. Drouin and G. Canuel for their technical support during laboratory and field works and reviewers for helpful suggestions. This research was supported by the Canada Research Chair program (E.P.) and the Natural Sciences and Engineering Research Council of Canada (NSERC Discovery grant). This paper is a contribution of Quebec-Ocean network. 


\section{$\underline{\text { References }}$}

An, S., Gardner, W.S., 2002. Dissimilatory nitrate reduction to ammonium (DNRA) as a nitrogen link, versus denitrification as a sink in a shallow estuary (Laguna Madre/Baffin Bay, Texas). Marine Ecology Progress Series, 237, 41-50.

Anchutz, P., Sundby, B., Lefrançois, L., Luther III, G.W., Mucci, A., 2000. Interactions between metal oxides and species of nitrogen and iodine in bioturbated marine sediments. Geochimica et Cosmochimica Acta, 64, 2751-2763.

Aspen, R.J., Vardy, S., Paterson, D.M., 2004. Salt marsh microbial ecology: microbes, benthic mats and sediment movement. In: Fegherazzi, S., Marani, M.,. Blum, L.K. (Eds.), The ecogeomorphology of tidal marshes. Coastal and Estuarine Studies, American Geophysical Union, pp. 115-135.

Aziz, S.A.A., Nedwell, D.B., 1986. The nitrogen cycle of an East Coast, U.K. saltmarsh: II. Nitrogen fixation, nitrification and denitrification, tidal exchange. Estuarine, Coastal and Shelf Science, 22, 689-704.

Blackburn, T.H., Sorensen, J., 1988. Nitrogen cycling in coastal marine environments. John Wiley and Sons, New-York, pp.1-451.

Boorman, L.A., 1999. Salt marshes - Present function and future change. Mangroves and Salt marsh, 3, 227-241. 
Cataxana, P., Lloyd, D., 1999. $\mathrm{N}_{2}, \mathrm{~N}_{2} \mathrm{O}$ and $\mathrm{O}_{2}$ profiles in a Tagus Estuary salt marsh.

Estuarine, Coastal and Shelf Science, 48, 751-756.

Cloern, J.E., 2001. Our evolving conceptual model of the coastal eutrophication problem. Marine Ecology Progress Series, 210, 223-253.

Dauwe, B., Middelburg, J.J., 1998. Amino acids and hexosamines as indicators of organic matter degradation state in North Sea sediments. Limnology and Oceanography, $43,782-798$.

Dauwe, B., Middelburg, J.J., Herman, P.M.J., Heip, C.H.R., 1999. Linking diagenetic alteration of amino acids and bulk organic matter reactivity. Limnology and Oceanography, 44, 1809-1814.

Dionne, J.C., 1986. Érosion récente des marais intertidaux de l'estuaire du Saint-Laurent. Géographie Physique et Quaternaire, 50, 307-323.

Dionne, J.C., 1998. Sedimentary structure made by shore ice in muddy tidal-flat deposits, St. Lawrence Estuary, Québec. Sedimentary Geology, 116, 261-274.

Duarte, C.M., 1995. Submerged aquatic vegetation in relation to different nutrient regimes. Ophelia, 41, 87-112. 
Drapeau, G., 1992. Dynamique sédimentaire des littoraux de l'estuaire du Saint-Laurent. Géographie Physique et Quaternaire, 46, 233-242.

Eriksson, P.G., Svensson, J.M., Carrer, G.M., 2003. Temporal change and spatial variation of soil oxygen consumption, nitrification and denitrification rates in a tidal marsh of the Lagoon of Venise, Italy. Estuarine, Coastal and Shelf Science, 58, 861-871.

Gearing, J.N., Pocklington, R., 1990. Organic geochemical studies in the St. Lawrence Estuary. In: El-Sabh, M.I., Silverberg, N. (Eds.), Oceanography of a large-scale estuarine system, the St. Lawrence. Springer-Verlag, New York, pp. 170-195.

Gottschalk, G., 1979. Bacterial Metabolism. Springer-Verlag, New-York, pp.101-103.

Hamersley, M.R., Howes, B.L., 2005. Evaluation of the $\mathrm{N}_{2}$ flux approach for measuring sediment denitrification. Estuarine, Coastal and Shelf Science, 62, 711-723.

Herbert, R.A., 1999. Nitrogen cycling in coastal marine ecosystems. FEMS Microbial Reviews, 23, 563-590.

Howarth, R.W., 1988. Nutrient limitation of net primary production in marine ecosystems. Annual Review of Ecology and Systematics, 19, 89-110. 
Jenkins, M.C., Kemp, W.M., 1984. The coupling of nitrification and denitrification in two estuaries sediment. Limnology and Oceanography, 29, 609-619.

Jickells, T.D., Rae, J.E., 1997. Biogeochemistry of intertidal sediment. In: Jickells, T.D., Rae, J.E. (Eds.), Biogeochemistry of intertidal sediment. Cambridge Environmental Chemistry Series, U.K., pp. 2-15.

Jickells, T., 2005. External input as a contributor to eutrophication problems. Journal of Sea Research, 54, 58-69.

Joye, S.B., Hollibaugh, J.T., 1995. Sulfide inhibition of nitrification influences nitrogen regeneration in sediment. Science, 270, 623-625.

Kaplan, W., Valiela, I., Teal, J.M., 1979. Denitrification in salt marsh ecosystem. Limnology and Oceanography, 24, 726-734.

King, D., Nedwell, D.B., 1985. The influence of nitrate concentration upon the endproduct of nitrate dissimilation by bacteria in anaerobic salt marsh sediment. FEMS Microbiology Ecology, 31, 23-28.

Knowles, R., 1981. Denitrification. In: Clark, F.E., Rosswall, T. (Eds.), Terrestrial Nitrogen Cycle. Processes, Ecosystem Strategies and Management Impact, Ecology Bulletin, Stockholm, pp. 315-330. 
Koch, M.S., Malby, E., Oliver, G.A., Bakker, S.A., 1992. Factor controlling denitrification rates of tidal mudflats and fringing salt marshes in South-west England. Estuarine, Coastal and Shelf Science, 34, 471-485.

Lindroth, P., Mopper, K., 1979. High performance liquid chromatographic determination of subpicomole amounts of amino acids by precolumn fluorescence derivatization with $o$ phthaldialdehyde. Analytical Chemistry, 51, 1667-1674.

Louchouarn, P., Lucotte, M., Canuel, R., Gagné, J.-P., Richard, L.-P., 1997. Sources and early diagenesis of lignin and bulk organic matter in the sediments of the Lower St. Lawrence Estuary and the Saguenay Fjord. Marine Chemistry, 58, 3-26.

Lucotte, M., Hillaire-Marcel, C., Louchouarn, P., 1991. First-order organic carbon budget in the St. Lawrence lower Estuary from ${ }^{13} \mathrm{C}$ data. Estuarine, Coastal and Shelf Science, $32,297-312$.

Luther, G.W., Sundby, B., Lewis, B.L., Brendel, P.J., Silverberg, N., 1997. Interactions of manganese with nitrogen cycle: alternative pathways to dinitrogen. Geochimica et Cosmochimica Acta, 61, 4043-4045.

Morisette, A., 2006. Évolution côtière haute résolution de la région de Longue-RiveForestville, Côte Nord de l'estuaire maritime du Saint-Laurent. Mémoire, Université du Québec à Rimouski, Québec. 
Nielsen, L.P., 1992. Denitrification in sediment determined from nitrogen isotope pairing. FEMS Microbiology Ecology, 86, 357-362.

Nixon, S.W., 1981. Remineralization and nutrient cycling in coastal marine ecosystems. In: Neilson, B.J., Cronin, L.E. (Eds.), Estuaries and Nutrients, Humana Press, Clifton, New Jersey, pp. 111-138.

Nowicki, B.L., Kelly, J.R., Requintina, E., Keuren, D.V., 1997. Nitrogen losses through sediment denitrification in Boston Harbor and Massacchussetts Bay. Estuaries, 20, 626639.

Pantoja, S., Lee, C., 2003. Amino acid remineralization and organic matter lability in Chilean coastal sediment. Organic Geochemistry, 34, 1047-1056.

Poulin, P., Pelletier, E., 2006. Determination of ammonium using a microplate-based fluorometric technique. Talanta, in press.

Punshon, S., Moore, R.M., 2004. Stable isotope technique for measuring production and consumption rates of nitrous oxide in coastal water. Marine Chemistry, 86, 159-168. 
Risgaard-Petersen, N., 2003. Coupled nitrification-denitrification in autotrophic and heterotrophic estuarine sediment: On the influence of benthic microalgae. Limnology and Oceanography, 48, 93-105.

Seitzinger, S.P., 1988. Denitrification in fresh and coastal marine ecosystems: ecological and geochemical significance. Limnology and Oceanography, 33, 702-724.

Serodes, J.-B., Dubé, M., 1983. Dynamique sédimentaire d'un estran à Spartines. Le Naturaliste Canadien, 110, 11-26.

Silverberg, N., Bakker, J., Edenborn, H.M., Sundby, B., 1987. Oxygen profiles and organic carbon fluxes in the Laurentian Trough sediment. Netherlands Journal of Sea Research, 21, 95-105.

Silverberg, N., Sundby, B., Mucci, A., Zhong, S., Arakaki, T., Hall, P., Landen, A., Tengberg, A., 2000. Remineralization of organic carbon in eastern Canadian continental margin sediment. Deep-Sea Research Part II, 47, 699-731.

Simek, M., Cooper, J.E., 2002. The influence of soil pH on denitrification: Progress towards the understanding of this interaction over the last 50 years. European Journal of Soil Science, 53, 345-354. 
Smith, C.J., DeLaune, R.D., Patrick, W.H., 1985. Fate of riverine nitrate entering an estuary: I. Denitrification and nitrogen burial, Estuaries, 8, 15-21.

Sorensen, J., 1978. Denitrification rates in marine sediment as measured by the acetylene inhibition technique. Applied Environmental Microbiology, 36, 139-143.

Strickland, J.D.H., Parson, T.R., 1972. A practical handbook of seawater analysis.

Fisheries Research of Canada, Ottawa, pp.1-310.

Sundbäck, K., Miles, A., Göransson, E., 2000. Nitrogen fluxes, denitrification and role of microphytobenthos in microtidal shallow-water sediment, an annual study. Marine Ecology Progress Series, 200, 59-76.

Thamdrup, B., Würgler Hansen, J., Jørgensen, B.B., 1998. Temperature dependence of aerobic respiration in a coastal sediment. FEMS Microbiology Ecology, 25, 189-200.

Thompson, S.P., 1995. Seasonal pattern of nitrification and denitrification in a natural and a restored salt marsh. Estuaries, 18, 399-408.

Tuominen, L., Heinanen, A., Kuparinen, J., Nielsen, L.P., 1998. Spatial and temporal variability of denitrification in sediment of the Northern Baltic Proper. Marine Ecology Progress Series, 172, 13-24. 
Valiela, I., Teal, J.M., Persson, N.Y., 1976. Production and dynamics of experimentally enriched salt marsh vegetation, below ground biomass. Limnology and Oceanography, $21,245-252$.

Wang, F., Juniper, S.K., Pelegri, S.P., Macko, S.A., 2003. Denitrification in sediment of the Laurentian Trough, St. Lawrence Estuary, Québec, Canada. Estuarine, Coastal and Shelf Science, 57, 515-522.

Weiss, R.F., 1970. The solubility of nitrogen , oxygen and argon in water and seawater. Deep-Sea Research, 17, 721-735.

Yoon, W.B., Benner, R., 1992. Denitrification and oxygen consumption in sediment of two Texas estuaries. Marine Ecology Progress Series, 90, 157-167. 
Table 1 : Geochemical characteristics (mean values) of sediment samples collected in St.

Lawrence Estuary salt marsh in 2005.

\begin{tabular}{|c|c|c|c|c|c|c|c|c|}
\hline Sample & $\begin{array}{l}\text { Grain } \\
\text { size }\end{array}$ & $\mathrm{N}$ & $\mathrm{C}$ & $\mathrm{C} / \mathrm{N}$ & {$[\mathrm{Mn}]$} & {$[\mathrm{Fe}]$} & & DI \\
\hline$(\mathrm{y} / \mathrm{m} / \mathrm{d})$ & $(\mu \mathrm{m})$ & $(\%)$ & $(\%)$ & & $(\mu \mathrm{mol} \mathrm{g}$ & $\left.\mathrm{mol} \mathrm{g}^{-1}\right)$ & $\left.\mu \mathrm{mol} \mathrm{g}{ }^{-1}\right)$ & \\
\hline $2005-08-10$ & 109.6 & 0.55 & 6.53 & 13.96 & 0.04 & 4.34 & 58.28 & -0.66 \\
\hline $2005-08-10$ & 109.5 & 0.54 & 9.00 & 19.35 & 0.04 & 4.36 & 49.27 & -0.69 \\
\hline $2005-08-10$ & $\mathrm{ND}^{1}$ & ND & ND & ND & ND & ND & 59.58 & -0.66 \\
\hline 2005-10-04 & 198.5 & 0.61 & 6.91 & 13.19 & 0.07 & 4.17 & ND & ND \\
\hline $2005-10-04$ & 167.4 & 0.56 & 8.18 & 17.01 & 0.04 & 4.52 & ND & ND \\
\hline 2005-12-06 & 156.5 & 0.55 & 6.96 & 14.86 & 0.08 & 4.63 & ND & ND \\
\hline $2005-12-06$ & 145.3 & 0.56 & 7.67 & 16.11 & 0.08 & 4.84 & ND & ND \\
\hline
\end{tabular}

${ }^{1}$ not determined 


\section{Figure Captions}

Figure 1 : Map of Pointe-au-Père salt marsh located along the St-Lawrence Estuary south shore in Rimouski. The white area represents the infra-littoral zone, dark grey area the inter-tidal zone and light grey area the supra-littoral zone. The black square represents the $10-\mathrm{m}^{2}$ sampling area.

Figure 2 : Contribution of denitrification rates produced within the sediment cores by nitrification (Dn in grey) and denitrification rates coming from overlying water (Dw in black) to total denitrification (Dt) as a function of incubation temperatures. Values represent mean $\pm \operatorname{SD}(n=8)$.

Figure 3 : Dissolved oxygen uptake rates as a function of incubation temperatures. Values represent mean $\pm \mathrm{SD}(\mathrm{n}=4)$.

Figure 4 : Nitrate consumption rates (in grey) and ammonium production rates (black) as a function of incubation temperatures. Values represent mean $\pm \operatorname{SD}(n=4)$.

Figure 5 : Typical HPLC chromatogram of THAA extracted from Pointe-au-Père salt marsh sediment sampled in August 2005. main identified amino acids are aspartic acid (Asp), glutamic acid (Glu), serine (Ser), threonine (Thr) and alanine (Ala). 
FIGURE 1

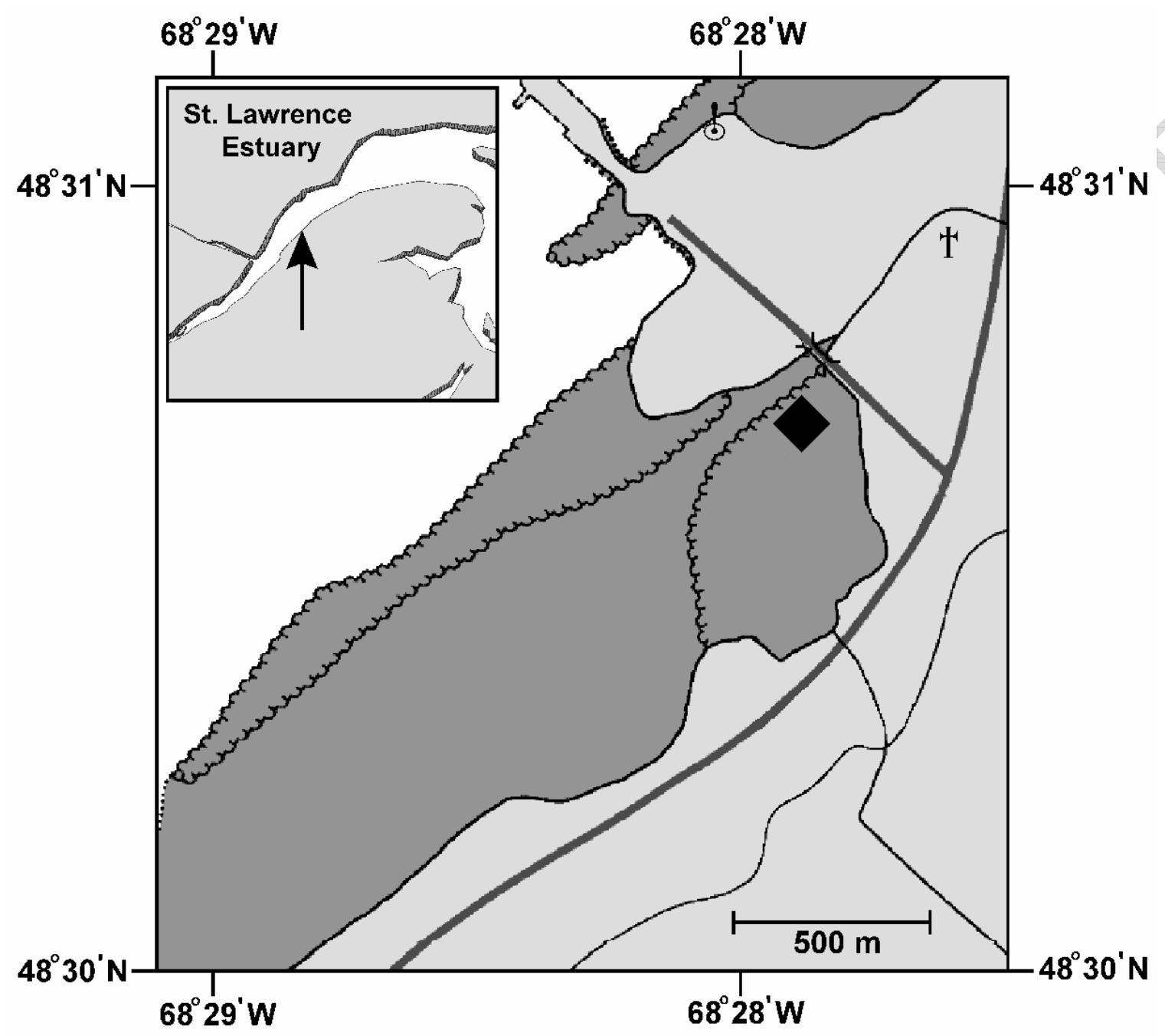


FIGURE 2

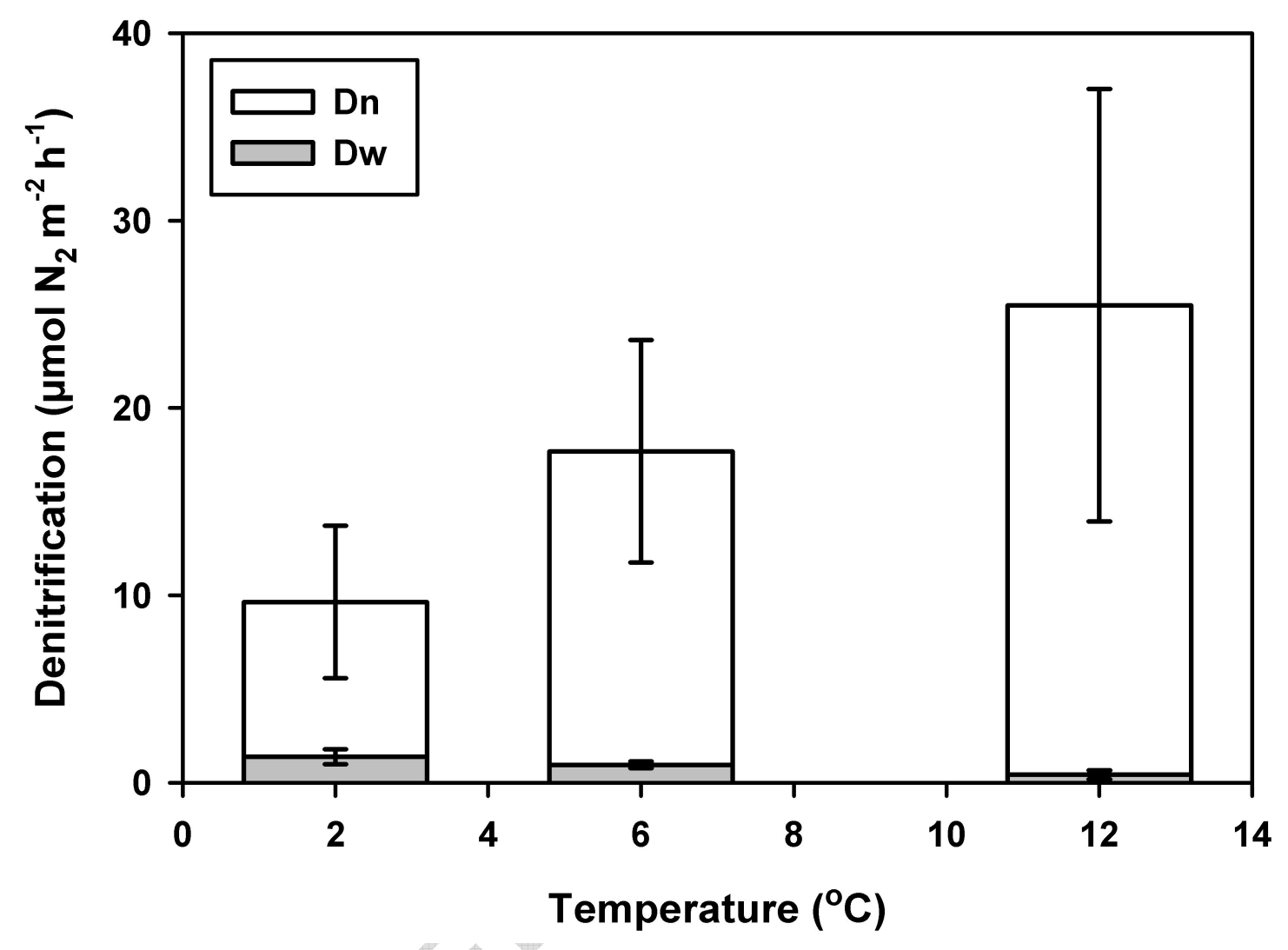


FIGURE 3

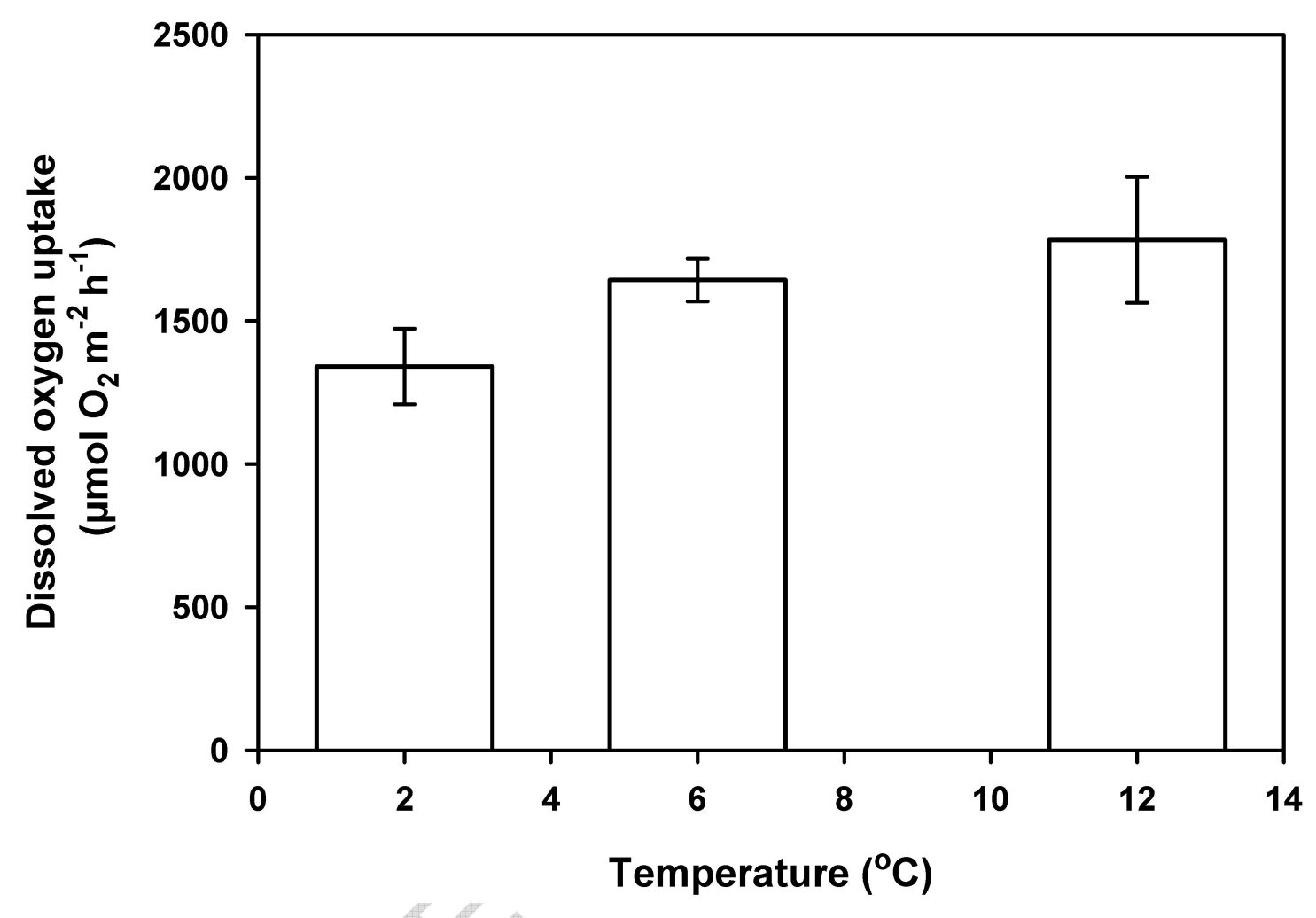


FIGURE 4

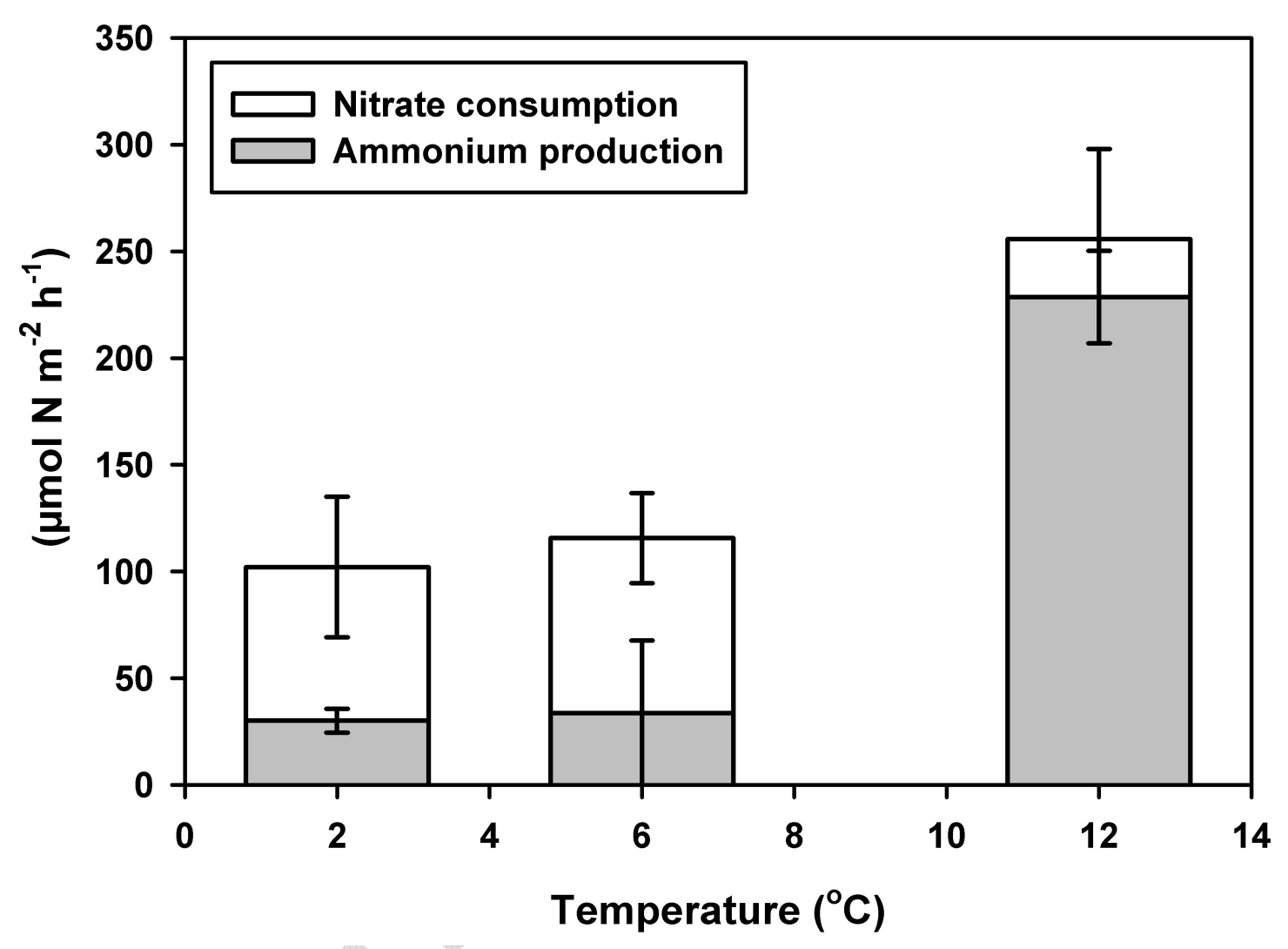




\section{FIGURE 5}

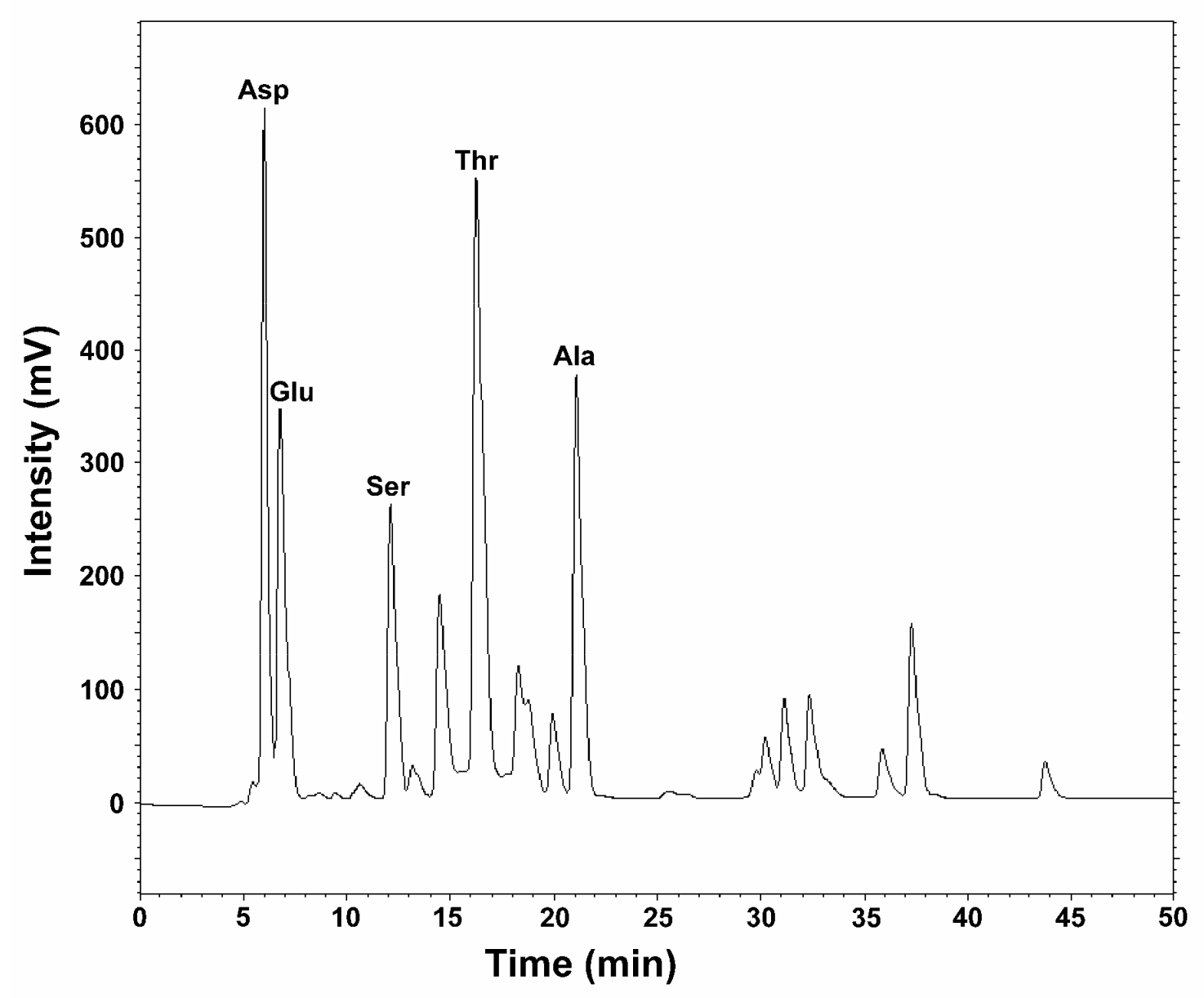

